Martin D. Henry (ITQ, vol. 68/4, 2003, 392-95)

\title{
Franz Overbeck on Carl Albrecht Bernoulli
}

In 1897 Franz Overbeck's ${ }^{1}$ pupil, C.A. Bernoulli, ${ }^{2}$ published a long essay on his ideas for a new method in theology, entitled Die wissenschaftliche und die kirchliche Methode in der Theologie. Ein enzyklopädischer Versuch (The Academic and the Church-Based Method in Theology. A General Essay). On the first blank page of his own copy of this book, ${ }^{3}$ Overbeck in the same year wrote some brief comments on this work, which are here translated. Part of the interest of this short piece lies in the concise and candid statement it contains of Overbeck's fundamental attitude to theology and Christianity. In the following few years, he added, again in his own copy of the book, a further few comments to the remarks he had initially written. All but one of these additions are also translated here. The original German text follows below after the translation.

I wrote my tract, How Christian is present-day theology?, in the conviction that our age is in the process of dismantling the church altogether and of seeking a completely new way of understanding Christianity, indeed a new

See M. Henry, 'Franz Overbeck: An Introduction', ITQ 65 (2000), 307-318.

Carl Albrecht Bernoulli (1868-1937) taught church history as a privat-docent in Basel from 1895-97. The publication of Die wissenschaftliche und die kirchliche Methode in der Theologie (in 1897) ended his university career temporarily. Subsequently, he lived as a free-lance writer in Paris, London, and Berlin, before returning to Switzerland in 1906, settling in Arlesheim, near Basel. In 1922 he was again a privat-docent in Basel, for the history of religion; in 1926 he became associate professor for church history (see N. Peter, art. 'Bernoulli, Carl Albrecht', in Historisches Lexikon der Schweiz, vol. 2, (Basel: Schwabe Verlag, 2003), 312f.). Now in the possession of the translator. The book contains a loose sheet on which Overbeck initially sketched out his comments, before writing them into the first blank page of Bernoulli's Essay. The additions were written on the reverse side of the first blank page, and on the final blank page at the back of the book. 
way of understanding religion in general. In writing my tract, I felt no hatred or aversion to either the church or Christianity. They were never a thorn in my flesh. I have never experienced them as in any way oppressive. If there is anything in the tract I am referring to, against which I do harbour any such negative feelings, then it is theology (and to that extent, of course, the church too). I certainly do not wish to have anything personally to do with theology any more. I wish, rather, to be free of it, in order to get on with my own work. Indeed, as far as theology is concerned, I don't care two hoots about it. And if that is how everyone now regards my attitude towards theology, then that is fine by me. The role that the church and Christianity play in the world is something that, in a certain sense, never was, and is not now, any of my business. But I have always thought and I still think that theology has never been anything but harmful; it is something that I, at any rate, want nothing to do with, and consequently do not recommend anyone else to get involved with either.

Now on this very question, Bernoulli, who is supposed to be my pupil, shows in this 'General Essay' that he has not even begun to understand what my position is. I myself, of course, never dreamt - until it actually happened - that I would one day be asked to sponsor an 'endeavour' like Bernoulli's. Furthermore, to count me among prophets of Lagarde’s ${ }^{4}$ ilk, I can only regard as an appalling misunderstanding, one I did not intend, nor, I think, could be held responsible for. As far as the two of us (Lagarde and myself) were concerned, my tract certainly did not bring us any closer together. As

4 On Paul Anton de Lagarde, see M. Henry, 'Franz Overbeck: An Introduction', ITQ 65 (2000), 316, n. 34. Overbeck discussed Lagarde’s ideas on the future of theology in the fifth and final chapter of his tract, How Christian is Our Present-day Theology? (1873). 
time went on, we gradually just grew further and further apart. Lagarde's taste for rhetoric was something I could never warm to. I eventually came to find it utterly repugnant. What he did not like in me, I have never had an opportunity to discover; except that he let anyone interested in hearing such comments know that he had nothing, or at least nothing more, to do with me - and, furthermore, he mentioned this as something that was generally acknowledged. (July 1897).*5

[*The gist of these remarks I myself 'intimated' orally to the author of this book, ${ }^{6}$ during his stay in Basel in January 1902. This was, naturally, after a lot had already happened to enable us to understand each other's position better (especially when we had a week-long get-together in the Vosges in August 1900), and after the author himself had done a lot especially from the time he took leave of absence as a privat-docent in theology in the autumn of 1897 - to break away from the approach to theology he had followed in this work. (September 1902). Cf. now my How Christian is Our Present-day Theology?, $2^{\text {nd }}$ edition (Leipzig, 1903), 198f.]

I am also happy to see that certain individual reviewers of Bernoulli's book (W. Herrmann ${ }^{7}$ and also F. Hubert) have appealed to me, in their discussion of his work, against Lagarde. I should just like to have a better idea how Herrmann himself proposes to get rid of his own penchant for

5 This asterisk refers to the following note that Overbeck subsequently added to his original comments on Bernoulli's book.

$6 \quad$ I.e. Bernoulli's Essay.

7 Wilhelm Herrmann (1846-1922), a 'Liberal Protestant', was a disciple of Albrecht Ritschl's (1822-1889), and a teacher of both Karl Barth and Rudolf Bultmann in Marburg. 
rhetoric, even if his rhetoric is not quite as self-indulgent as Lagarde's. (13 May '98).

Cf. F. Hubert, Deutsche Literaturzeitung (1898), col. 621, where he says that Bernoulli has 'not yet learnt anything from the excellent critique of Lagarde by his teacher Franz Overbeck.'

Bernoulli's book is taken up by G. Krüger' in his essay 'Unchristian Theology' (Die christliche Welt 34, 1900, cols. 804ff.), an essay combining the paradoxical and the trivial in a masterly fashion that is to be found, not infrequently, in the writings of 'modern theologians' in particular.

Roughly at the same time as Bernoulli, W. Wrede published The Task and Methods of 'New Testament Theology' (Göttingen, 1897; 80 pages). ${ }^{9}$ This work appears to me, at a quick glance, to have a strikingly close affinity with Bernoulli's. The kind of questions they deal with seem to have become a fashionable subject of discussion among today's educated theological youth. It's a bad sign when the youth wants to instruct us in questions of 'method'! Not much can be expected from such works beyond seeing in

8 Gustav Krüger (1862-1940), church historian, who taught in Giessen from 1886 until his retirement in 1927, was sympathetic to 'Liberal Protestantism' (which is what Overbeck has in mind in referring to 'modern theologians'), one of whose principal organs was the journal, Die christliche Welt (1877ff.). His views on theology were discussed by Bernoulli in his Essay. Overbeck's letters to Krüger were published by the latter: 'Overbeckiana', Theologische Blätter 15 (1936), cols. 100-104.

$9 \quad$ This monograph by William Wrede (1859-1906), who taught in Breslau from 1893 until his death, was translated into English, under the title given above, by Robert Morgan in The Nature of New Testament Theology (London: SCM, 1973), 68-116. 
them the expression of a certain dissatisfaction with the current state of affairs, and that might still be the best thing about them.

German original of the above translation: ${ }^{10}$

Meine 'Christlichkeit der heutigen Theologie' ist unter dem Eindruck geschrieben, dass wir in einer Zeit leben, die im Begriff ist, die Kirche abzutragen und zum Christentum, zur Religion überhaupt, sich ein vollkommen neues Verhältnis zu geben. Dabei schreibe ich ohne Hass und Widerwillen gegen Kirche und Christentum, zu denen ich nie einen Stachel zu empfinden bekommen. Sie haben mich nie bedrückt. Hege ich gegen etwas in der genannten Schrift Empfindungen der Art, so ist es die Theologie (und in ihr freilich die Kirche). Die Theologie allerdings will ich für mich abtun, von ihr frei für meine Arbeit sein, und in Hinsicht auf sie auch in jedermanns Urteil dafür gelten, dass ich mich um sie den Kuckuck schere. Was Kirche und Christentum in der Welt sind, ging und geht mich in gewissem Sinne nichts an; von der Theologie aber dachte und denke ich nicht anders, als dass sie stets ein Übel gewesen, mit dem ich jedenfalls nichts zu schaffen haben wolle und demnach auch sonst niemandem sich zu schaffen zu machen empfehle. Eben davon hat nun mein vermeintlicher Schüler Bernoulli in diesem ‘Enzyklopädischen Versuch’ auch nicht das erste Wort verstanden. Ich selbst habe es mir allerdings, bis es geschehen

10 In Overbeck's German text, abbreviations have here been removed, the spelling modernized, proper names given in roman script, titles of books and journals in italics (in the original, the opposite is the case), and some punctuation added for the sake of clarity. 
war, nicht träumen lassen, dass ich noch bei einem solchen 'Versuch' zu Gevatter gebeten werden würde. Mich zu den Propheten der Art Lagardes zu stellen, erscheint mir auch nur wie ein ungeheueres, von mir nicht beabsichtigtes, und, ich meine, auch nicht verschuldetes Missverständnis. Wir beide (Lagarde und ich) selbst sind uns auch durch meine Schrift gewiss nicht näher gerückt und später allmählich nur immer ferner. Lagardes Rhetorenart hat mich nie für ihn warm werden lassen; schließlich wurde sie mir herzlich widerwärtig. Was er an mir nicht gemocht, habe ich nie zu erfahren Gelegenheit gehabt; nur dass er jedem, der in den Wurf einer solchen Äußerung kam, als etwas übrigens Notorisches kund und zu wissen tat, dass er mit mir nichts oder nichts mehr zu tun habe. (Juli 1897).* ${ }^{11}$

[*Dem Verfasser dieses Buchs durch persönliche Vorlesung 'intimiert' bei seiner Anwesenheit in Basel, Januar 1902, nachdem natürlich manches zu unserer Verständigung vorangegangen war (insbesondere bei unserem achttägigen Zusammensein in den Vogesen, August 1900) und der Verfasser selbst, insbesondere seit seinem als Privatdozent der Theologie im Herbst 1897 genommenen Urlaub, manches getan, um sich selbst aus den in dieser Schrift verfolgten Bahnen herauszuwerfen. (September 1902). Vgl. jetzt meine 'Christlichkeit unserer heutigen Theologie', 2. Auflage, Leipzig, 1903, S. 198f.]

Auch sehe ich gern von einzelnen Rezensenten Bernoullis (W. Herrmann und auch F. Hubert) mich bei ihm gegen Lagarde aufgerufen. Wüsste ich nur von Herrmann besser, wo er selbst die Rhetorik los wird,

11 See above, n. 5. 
mag auch die seine von weniger selbstgefälliger Art sein, als die Lagardes. (13. Mai 98).

Vgl. F. Hubert, Deutsche Literaturzeitung 1898 Sp. 621: Bernoulli habe 'noch nichts gelernt ${ }^{12}$ von der ausgezeichneten Kritik, welche sein Lehrer Franz Overbeck an Lagarde geübt hat.'

An Bernoullis Buch knüpft der Paradoxie und Trivialität in einer besonders unter 'modernen Theologen' nicht selten anzutreffenden Meisterschaft verbindende Aufsatz von G. Krüger, 'Die unchristliche Theologie’ (Die christliche Welt, 1900, N 34, Sp. 804ff.) an.

Etwa gleichzeitig mit Bernoulli erscheint W. Wrede, Über Aufgabe und Methode der sogenannten neutestamentlichen Theologie (Göttingen, 1897; 80 Seiten). Die Schrift erscheint mir bei oberflächlichem Einblick auffallend geistesverwandt. Dergleichen Fragen scheinen unter der gebildeten theologischen Jugend des Tages ein Modegegenstand zu werden. Schlimm, wenn die Jugend Lehrmeisterin in der 'Methode' werden will! Viel mehr als der Ausdruck einer gewissen Verstimmung gegen die bestehenden Zustände ist nicht zu erwarten, und das mag noch das Beste daran sein.

12 This has been changed from 'noch nicht von gelernt', which seems to be a slip of the pen. 